\title{
Programmes of frivolity on ice? \\ Hockey, business, diasporic identity and apartheid \\ in South Africa, 1936-1992
}

Hendrik Snyders ${ }^{*}$

\begin{abstract}
South Africa has a surprisingly long history of the sport perhaps most usually associated with the northern hemisphere: ice hockey. Ice skating was first introduced in the country in the last decade of the nineteenth century as a commercial venture. Entrepreneurs built ice rinks for profit-making purposes and brought showmen from overseas to demonstrate the sport. An ancillary activity was the establishment of ice hockey clubs in 1936 and beyond. Given the strong profit motive, personal and tactical differences between the chief investors and sports administrators inevitably left its imprint on the sport. The extensive involvement of German, Canadian and Swiss immigrants throughout the twentieth century also co-determined the eventual character of the sport. From its inception through to 1991, ice hockey practised racial segregation, operated within apartheid laws and remained an exclusively white activity. Unsurprisingly, the apartheid ice rink also became embroiled in global politics, became a target of the worldwide anti-apartheid sports boycott and was excluded from all international competition from the late 1960s until 1991. This article reclaims some of ice hockey's neglected history in South Africa and investigates the interplay of sport, ice rink entrepreneurship, imperial and foreign identity, and apartheid politics during the twentieth century.
\end{abstract}

Keywords: Hockey; ice skating; segregation; apartheid; South African sport; boycott; diaspora; business.

Hendrik Snyders received his doctorate in History in 2011 from the University of Stellenbosch and is head of the Department of History at the National Museum Bloemfontein. He is also a research fellow at the Department of History of the University of the Free State.

How to cite this article: H. Snyders, "Programmes of frivolity on ice? Hockey, business, diasporic identity and apartheid in South Africa, 1936-1992", Historia, 65, 1, May 2020, pp 87-118. 


\section{Opsomming}

Suid Afrika het 'n lang verbintenis met yshokkie - 'n sport wat oor die algemeen met Noord Amerika geassosieer word. Yshokkie se plaaslike teenwoordigheid kan direk verbind word na die vestiging van rolskaatsbane as 'n entrepreneursinisiatief deur sakemanne gedurende die laat-negentiende eeu. In 'n poging om munt te slaan uit die openbare belangstelling in rol- en ysskaats, is vertoonkunstenaars vanaf oorsee ingevoer om deur middel van openbare demonstrasies plaaslike belangstelling aan te wakker wat op hulle beurt, weer tot die stigting van verskeie yshokkie klubs in 1936 aanleiding gegee het. Gegewe die sterk winsoogmerke agter die inisiatief, was dit feitlik onafwendbaar dat verskille en geskille tussen sakevennote en administrateurs, die ontwikkelingsgang en uiteindelike karakter van die sport direk sou beïnvloed. Suid Afrika se lang geskiedenis van rasseskeiding, apartheid (1948-1991) en die betrokkenheid van 'n groot groep oorsese spelers (Duitsers, Switsers en Kanadese) het eweneens Suid Afrikaanse yshokkie se finale identiteit help vorm. Gegewe die sport se slegs-blankes aard gedurende die apartheidsera, het dit soos ander sportsoorte 'n teiken van die internasionale anti-apartheid boikot-veldtog geword. Hierdie artikel poog eerstens om elemente van yshokkie se Suid Afrikaanse verlede aan die vergeteldheid te ontruk en tweedens, om die wisselwerking tussen die sport, entrepreneurskap, imperiale- en buitelandse-identiteite en apartheid gedurende die 20ste eeu bloot te lê.

Sleutelwoorde: Hokkie; ysskaats; segregasie; apartheid; Suid-Afrikaanse sport; diaspora; ondernemerskap.

\section{Introduction}

In December 2019, against all the odds, South Africa won the gold medal in Division III of the International Ice Hockey's Women's World Championship in Sofia, Bulgaria. In addition to gaining promotion to the next division, team captain Donne van Doesburgh won the award for the best defender at the tournament. This performance, which journalist Tyler Leigh Vivier described as "a puck in for the gold!" saw South Africa eliminating a paltry pre-tournament record of only three victories in 13 appearances. ${ }^{1}$ Significantly, it was achieved against opponents with a strong ice hockey tradition (Belgium, Romania, Lithuania, Bulgaria and Hong Kong) and despite its lack of regular international competition and small player pool. ${ }^{2}$ Women's ice

1. T.L. Vivier, "South African Women's Ice Hockey go for Gold and Score!!!” Goodthingsguy.com, 11 December 2019. Available at https://www.goodthingsguy.com/ sport/sa-hockey-world-champs/ Accessed 14 September 2020.

2. I. Tchechankov, "First Triumph for South African Women", International Ice Hockey Federation, 11 December 2019, at https://www.iihf.com/en/events/ 2020/wwiii/news/ 16572/first-triumph-for-south-african-women Accessed 14 September 2020. 
hockey is not only a recent development in South Africa, but based on the 2015 statistics, females numbered only 50 out of a total playing group of 267 players. $^{3}$ Unsurprisingly, the euphoria that followed the victory of the Springboks after their Rugby World Cup victory in Japan in November 2019, completely overshadowed the ice hockey achievement. Rugby, given its wide geographical spread (14 provincial unions, six commercial franchises), and more than a century of recorded history is a regular feature in the mainstream media. ${ }^{4}$ In contrast, ice hockey, despite 83 years of existence (1936 to the present), and lacking a recorded history, remains on the margins. This has left South Africans at large, generally unaware of the sport's rich local past.

Against this background, this article attempts to reconstruct the history and development of the sport during the 20th century. The narrative is broadly divided into three sections. While the first section deals with the state of scholarship on South African ice hockey history, the next investigates the history of the sport before formal apartheid (pre-1948), including its evolution from roller skating and its intersection with the politics of the British Empire Exhibition. Section three investigates the development of the sport under apartheid until 1991, specifically its accommodation to and operational practices under the segregated political system, its semiprofessionalism, financial struggles and its intersections with the politics of multiracialism.

\section{The state of the game and scholarship}

South Africa is the oldest ice hockey-playing country on the African continent. Since its admission to the International Ice Hockey Association (IIHA) in 1937, the sport has developed a strong coordinating body, built rinks, formed clubs and selected national teams. This development coincides with the worldwide proliferation of ice rinks as commercial ventures from the late nineteenth century onwards. With no long tradition in amateur pastimes in white colonial or indigenous Africa, rather than developing due to popular demand, it was the capitalist drive for profit and entrepreneurial success which led to the sport's creation in the country and its subsequent promotion in the 1890s. So as to offer a ready-made and attractive product, local rink owners formed ice hockey clubs and, in 1937, established a league, usually populated by non-South African players from Europe and North America, most of whom were resident temporarily in Johannesburg and Durban.

3. D.C. van Doesburgh, "An Injury Profile of Ice Hockey Players in South Africa", MTech dissertation, Durban University of Technology, 2017, p 27.

4. See for example P. Dobson, Rugby in South Africa, 1861-1988 (South African Rugby Board, Cape Town, 1989); and W. van der Berg, 150 Years of South African Rugby (Bookstorm, Johannesburg, 2011). 
The South African ice hockey past has remained an unmapped landscape that "continues to exist outside the dominant discourse" of both the local and global history of sport. ${ }^{5}$ The only existing account lacks both depth and critical context and generally fails to acknowledge the role of apartheid laws and ideology on its development. ${ }^{6}$ The present study, in line with recent calls for more scholarship on the subject such as by North American ice hockey scholars, Holman and Stevens, aims to unearth a mostly hidden history and to provide a more nuanced understanding of South Africa's sporting past so as to situate it within debates about "new racism and old stereotypes" and the decolonisation of the international game. ${ }^{7}$

Historian Andre Odendaal for example, has criticised the persistent myth within white sporting communities and the local media "that current inequalities in rugby [and most other sport for that matter] evolved naturally; that they existed because black South Africans were not interested in the game or were not suited to it, psychologically, emotionally and physically". ${ }^{8}$ Such notions feed into the oftenacrimonious debates about the need for the acceleration of black players, officials and administrators, racially-based selection quotas and the call for demographic transformation of South African sport at all levels. ${ }^{9}$ Further, many South Africans continue to believe that sport was "not intrinsically linked to the shame of apartheid". ${ }^{10}$ These persistent tropes and their repeated promotion by the local media have contributed to the deepening of existing silences about a variety of sporting codes and communities on the margins of historiography. ${ }^{11}$

5. J. Stevens and A.C. Holman, "Rinkside: New Scholarly Studies on Ice Hockey and Society", Sport in Society, 16, 3, 2013, p 252.

6. B. Nordmark, "Ice Hockey in South Africa, Part 1, 1936-1980", Wayback Machine, 2 October 2006.

7. Stevens and Holman, "Rinkside", p 251. See also J. Valentine, "New Racism and Old Stereotypes in the National Hockey League: The 'Stacking' of Aboriginal Players into the Role of Enforcer", in J. Joseph, S. Darnell and Y. Nakamura (eds), Race and Sport in Canada: Intersecting Inequalities (Canadian Scholars' Press, Toronto, 2012); S. McKegney and T.J. Phillips, "Decolonizing the Hockey Novel", in A. Abdou and J. Dopp (eds), Writing the Body in Motion: A Critical Anthology on Canadian Sport Literature (Athabasca University Press, Edmonton, 2018).

8. A. Odendaal, "'The thing that is not round': The Untold Story of Black Rugby in South Africa" in A.M. Grundlingh, A.A. Odendaal and S.B. Spies, (eds), Beyond the Tryline: Rugby and South African Society (Ravan Press, Johannesburg, 1995), p 25.

9. J. Volschenk (ed.), Struggle-rugby: ' $n$ Sport in Krisis / Struggle Rugby: A Sport in Crisis (Solidariteit Navorsingsinstituut, Pretoria, 2002); L. le Grange, "Decolonising Sport: Some Thoughts", in F.J. Cleophas (ed.), Exploring Decolonising Themes in SA Sport History: Issues and Challenges (Sun Press, Stellenbosch, 2018), p 15; and Cubizolles, S., "Soccer in a Rugby Town: Restructuring Football in Stellenbosch", Soccer \& Society ,11, 1-2, 2010, pp 105-117.

10. J. Dunn, "Reconciliation and Rugby in Post-Apartheid South Africa", Seminar Paper, Levitt Summer Research Fellowship, Hamilton College, New York, 2009, p 3.

11. F.J.G. van der Merwe and F.J. Cleophas, "Mapping out an Obscured South African Sport History Landscape through Edward Henderson", African Journal for Physical Health Education, Recreation and Dance, 17, 2, 2011, pp 226-38. 
Given the close and continued association between ice hockey and white identity as well as hegemonic masculinity as analysed in other contexts (especially Canada and the United States of America) and South Africa's own chequered past as far as this sport is concerned, responding to the call by Holman and Stevens is a necessity. ${ }^{12}$ This present study therefore aims to expand current understandings of histories of the historical - and current - involvement of foreigners and the role of entrepreneurship (the "bona fide entertainment industry") in the development of South African sport generally and ice hockey in particular, as well as to debunk some of the existing myths in South African sport history. ${ }^{13}$

\section{From roller skating to ice rinks and ice hockey in South Africa}

The introduction of ice sports in South Africa unfolded incrementally from the late nineteenth century, and was mainly the initiative of entrepreneurs who discerned potential for profit in building ice rinks. One of the first was the Bloemfontein rollerskating rink established in 1891. These efforts were akin to developments elsewhere in the world, but from the outset were inflected by the prevailing racial order in South Africa. The Cape Argus newspaper remarked in 1894 that: "the races are best socially apart, each good in their own way, but a terribly bad mixture."14

Shortly after the South African War (1899-1902), American businessman, R.W.G. Webb, associated with the establishment of the Jubilee Exhibition Skating Plant (which included an ice-skating rink) in Britain and the Bloemfontein rollerskating rink, announced plans to build similar facilities in other South African cities. ${ }^{15}$ Given the establishment and management costs associated with ice rink construction, which would be estimated in 1911 as being between $£ 30000$ and $£ 42500$, this was an ambitious project. ${ }^{16}$ Exporting the activity to South Africa was considered to be a worthy undertaking because of the popularity of both roller - and ice skating and

12. C.A. MacDonald, "Masculinity and Sport Revisited: A Review of Literature on Hegemonic Masculinity and Men's Ice Hockey in Canada”, Canadian Graduate Journal of Sociology and Criminology, 3, 1, Spring 2014, p 95.

13. J.J. Wilson, "Skating to Armageddon: Canada, Hockey and the First World War", International Journal of the History of Sport, 22, 3, 2005, p 317.

14. Quoted in V. Bickford-Smith, Ethnic Pride and Racial Prejudice in Victorian Cape Town: Group Identity and Social Practice, 1875-1902 (Cambridge University Press, Cambridge, 1995), p 149.

15. J. Haasbroek, "Rolskaatsbane in Bloemfontein, 1909-1910: Rolskaatsbane in Bloemfontein gedurende die Republikeinse tydperk", Navorsinge van die Nasionale Museum / Researches of the National Museum, 14, 2, 1998, pp 47-49. See also "Roller Skating, the Craze Revived: A Night at the Jubilee Rink", Evening Journal (Adelaide, Australia), 18 May 1904. Available from the Australian National Library at https://trove.nla.gov.au/newspaper/ Accessed 20 May 2018.

16. Western Cape Archives and Record Service (hereafter KAB), Attorney-General's Division (hereafter AG) 1886:3542, Johannesburg Ice Skating Company, Souvenir of the Opening of 'Niagara', Johannesburg, 4 November 1911. 
their "meeting with a fair share of patronage" in Britain and then locally. Undoubtedly there were other influences too, such as the professionalisation of the game in Canada and the United States of America and the inauguration of domestic leagues and annual ice hockey internationals during the early years of the 20th century. ${ }^{17}$

In 1910, a newly incorporated business entity, Niagara Limited, established the Johannesburg Ice Skating Company. ${ }^{18}$ Eighteen months later, it opened the doors of the Niagara Ice Rink, named after similar establishments in both London and Australia. This facility added a further dimension to the ever-growing diversity of sports and sporting facilities in the Johannesburg-Pretoria area during a period that had also witnessed the introduction and expansion of sports such as lacrosse, Australian football and baseball. Others such as rugby, soccer (football) and cricket were already well-established and to a large extent enjoyed priority patronage from the residents of both cities.

From its opening, the Niagara competed with other facilities. The Johannesburg Roller-skating Rink, and the Capital Roller Rink in Pretoria, formed the backbone of rink skating sports in Transvaal. Looking for competitive advantage, the owners of the Johannesburg Ice Skating Company declared its objective to develop "skaters of sufficient prowess to host and compete in the great racing and figure skating championships" both locally and internationally. ${ }^{19}$ It thus offered ice-skating, curling and ice-dancing under the auspices of the Niagara Ice Skating Club and planned to establish ice hockey clubs as a key priority. Far from being motivated by the desire to promote sport for its own sake, these plans were part of the company's business strategy to ensure the financial survival of their facility.

In the short-term, Niagara Limited staged a variety of events including curling, musical performances, carnivals, boxing contests, and ice dancing since the facility's construction allowed for easy coverage of the ice surface. Although these activities were described by the company's competitors as "programmes of frivolity on ice", it followed established precedent and mirrored practices elsewhere undertaken to ensure their investors' financial survival. ${ }^{20}$ The Johannesburg Niagara Ice Rink also offered paying clients access to clubrooms, reading rooms, a lounge, and a skating store. The company advertised its facility as a space for the "tired man or woman", a "comfortable resort for all classes" and most importantly, as a "rendezvous for ladies

17. “Our South African Letter", Referee, 16 March 1910, p 15. See also D.S. Mason, "The International Hockey League and the Professionalization of Ice Hockey, 1904-1907", Journal of Sport History, 25, 1, Spring 1998; and D. Leeworthy, "The Skaters of Sydney and Streatham: Exporting Hockey to the British Empire between the Wars'”, Paper presented at the "Putting it on Ice" Hockey Conference, Saint Mary's University, Halifax, Nova Scotia, 12 to 14 July 2012.

18. KAB, AG, 1886:3542, Johannesburg Ice Skating Company, Souvenir of the Opening of 'Niagara', Johannesburg, 4 November 1911.

19. Johannesburg Ice Skating Company, “Souvenir", 4 November 1911, pp 7-8.

20. Mason, "The International Hockey League", p 2. 
visiting town". ${ }^{21}$ Through the Niagara Ice Skating Club, it also offered skating, ice dancing and figure-skating tuition and ad hoc events such as dinner parties, orchestral performances, Christmas festivities and holiday programmes for young people. In accordance with prevailing socio-political norms and rules, these activities and facilities were restricted to whites, irrespective of their origin or class, as was the case with other similar facilities where, as historian Andre Odendaal has noted, whiteness, foreignness, "authority and imperial lifestyle" came to be celebrated. ${ }^{22}$

Soon after the opening of the project, however, a shareholder dispute about the fairness of the share-division of Niagara Limited crippled the business. William Johnson, a refrigeration engineer who claimed both the idea and design blueprint of the facility, was adamant that the division disadvantaged him unfairly. Accusing his fellow shareholders of "fraud" and "impropriety" in the issuing of the company's founding prospectus, he threatened to take the matter to both the attorney general and to parliament. ${ }^{23}$ His co-shareholders dismissed the allegations and the matter degenerated into a drawn-out public spat and a breakdown in personal relationships. As a result, all operations of the rink ceased, which squeezed all the life out of business.

The first attempt to establish a local ice hockey tradition, therefore, failed. Its revival was hindered even further when South Africa entered the First World War in 1914, because many potential players and other sportsmen joined the war effort. Although some sports attempted to continue, lack of players forced them to either play ad hoc competitions or to resort to war leagues which, due to a player shortage, had a short life-span.

After the war, the demands of reconstruction and the challenges associated with the great flu epidemic of 1918 and 1919, and the worldwide depression of 1929-1933, left meagre financial resources for the revival of mass sport in South Africa or elsewhere. Quite soon, however, businessmen in countries such as Great Britain, the United States and Canada resumed the construction of ice rink facilities and founded new clubs. In Britain this was seemingly as a means of providing the English national team with a new generation of players "capable of meeting Canadians". ${ }^{24}$ With popular support and financial backing for sports, the need for greater club-level competitiveness and a rise in the quality of the "play on [the] ice and the spectacle that it provided" increased, a large number of Canadian and

21. KAB, AG, 1886:3542, Johannesburg Ice Skating Company, Souvenir of the Opening of 'Niagara', 4 November 1911.

22. A. Odendaal, "South Africa's Black Victorians: Sport and Society in South Africa in the Nineteenth Century", in J.A. Mangan (ed.), Pleasure, Profit, Proselytism: British Culture and Sport at Home and Abroad, 1700-1914 (Frank Cass, London, 1988), p 190.

23. KAB, AG 1886:3542, Correspondence: A. Hannay to Attorney General Cape Town, 13 March 1912.

24. "Sport in Britain: A Weekly Review", Ottawa Citizen, 8 March 1929. 
American players were recruited by British clubs. ${ }^{25}$ This benefited clubs such as those of the universities of Cambridge and Oxford, which became central in the promotion of ice hockey as a global sport - eventually including South Africa. ${ }^{26}$ At the start of the Winter Olympics at Garmisch-Partenkirchen in Bavaria, Germany, in 1936, however, South Africa had neither a dedicated national or regional coordinated body nor any clubs. This situation was to change with the hosting of the British Empire Exhibition as part of the City of Johannesburg's 50th anniversary (jubilee) celebrations in 1936.

\section{Ice hockey and the British Empire Exhibition, 1936-1937}

Nineteenth-century international exhibitions such as the Great Exhibition (1851) and its successors, including the British Empire Exhibition from 1924 onwards, drew the participation of teams from South Africa. These were important events for both the promotion of economic cooperation between Britain, her colonies, protectorates and dominions and for "celebrating imperial unity". ${ }^{27}$ They were also a platform for "presenting the latest products, tools and machines to stimulate 'enterprise' and 'progress'", 28 and to express "collective pride". ${ }^{29}$

The first British Empire Exhibition, held in 1924 and subsequently hosted at irregular intervals, saw Canada introducing the notion of sporting events and the simultaneous hosting of a British Empire Games, as "an alternative form of bond" for the Empire and as a critical signifier of national identity. ${ }^{30}$ Consequently, one of the (unrealised) plans for the 1933 Exhibition was to build a "great sports and pleasure palace" and a great display hall as part of the larger exhibition in London. ${ }^{31}$ The Empire Exhibition undoubtedly carried a significant volume of prestige. Johannesburg, a mining city in a what was by this time a thriving British dominion, was, therefore, an appropriate location for the hosting of an event "infused with high hopes and lofty purpose". 32

With due consideration to the former unrealised plans for an exhibition hallcum-sports arena as part of the event, the South African organisers included an ice rink in their infrastructural plan. The arena was to be constructed as an initiative by

25. Leeworthy, "The Skaters of Sydney", p 312.

26. D. Leeworthy, "Skating on the Border: Hockey, Class, and Commerce in Interwar Britain", Histoire Sociale / Social History, 48, 96, May 2015, p 203.

27. A. Clendinning, "Exhibiting a Nation: Canada at the British Empire Exhibition, 19241925", Histoire Sociale/Social History 39, 77, 2006, p 80.

28. B. Stoklund, "The Role of the International Exhibitions", Ethnologia Europaea, 24, 1, 1994, p 35.

29. Clendinning, "Exhibiting a Nation”, p 84.

30. K. Moore, “A Divergence of Interests: Canada's Role in the Politics and Sport of the British Empire during the 1920s", Canadian Journal of Sport, 21, 1, 1990, p 26.

31. Glasgow Herald, 7 July 1933, p 10.

32. S. Britton, “'Come and See the Empire by the All Red Route!': Anti-Imperialism and Exhibition in Interwar Britain", History Workshop Journal, 69, Spring 2010, p 70. 
Wembley (Pty) Limited, a private company led by local businessman Joseph Dorfman, on land close to the Wembley Stadium in Johannesburg, the main exhibition venue. Financial considerations undoubtedly motivated this project, positioned to profit from its association and proximity to the Empire Exhibition. With the opening of the rink in mind, the exhibition organisers invited teams from the universities of Oxford and Cambridge, prominent in the popularisation of the game in Europe at the time, to play in several exhibition games. ${ }^{33}$ Additionally, invitations were extended to Canadian clubs such as the Montreal Royals to host a match between a Canadian and an English team, as well as several exhibition games. ${ }^{34}$ However, all the latter negotiations failed. ${ }^{35}$

In July 1936, against the background of discussions about the nature and features of the exhibition, fifty ice hockey enthusiasts met at the Carlton Hotel in Johannesburg to consider the formation of an ice hockey club or clubs and a formal controlling body. This move was the result of an earlier call by the Old Edwardian Society to "any athletic club on the Reef which contemplates forming an ice hockey section" - and aimed to utilise the existing sports network, not necessarily to replace it. $^{36}$ Boasting 31 members, the society, being the alumni association of the King Edward VII School in the city, were engaged actively in ice-skating and played ice hockey informally at the rink in the South African Stadium in the suburb of Malvern. ${ }^{37}$

Several European and Canadian residents employed in the goldmines and at city businesses, as well as several interested local people "who have been getting into trim by practising on roller skates", joined them. ${ }^{38}$ Among those present were individuals such as James "Bubs" Britton, the Canadian assistant trade commissioner in South Africa, a former all-Canadian football and hockey player at Queens University in Toronto and the Argonauts Ice Hockey Club. Others included Rolland Desilets, formerly of the Capreol Canadian Northern Railways Hockey Club; John Evan Riddell, a former McGill University player; and a former Austrian international player, Wolfgang "Bobbie" Oppenheim. This group was set to play a seminal role in the establishment and growth of the sport in South Africa.

In recording these details of the names of the players, it is noteworthy that the process of giving nicknames, as Natalia Bobyreva observes, is a dynamic one and the "informal proper name given to a person in accordance with their unique characteristics and based on some analogy" conveys certain "subcultural

33. Leeworthy, "The Skaters of Sydney".

34. “Ice Hockey Finds a New Home”, Morning Bulletin, 17 October 1936, p 15.

35. "Sports on Parade", Montreal Gazette, 7 April 1936, p 14.

36. "Formation of Ice Hockey Association - Meeting on Monday", Rand Daily Mail, 10 July 1936, p 20.

37. “Ice Hockey on Roller Skates”, Rand Daily Mail, 14 July 1936, p 19; “Old Edwardians Ice Hockey - Practice Facilities Arranged”, Rand Daily Mail, 16 June 1936, p 19.

38. "Ice Hockey - New Home in South Africa", Auckland Star, 14 October 1936, p 21. 
information". ${ }^{39}$ While some nicknames are merely terms of endearment and signifiers of an athlete's recognition, achievements and popularity, the practice can also be an example of masculine signalling. In an essay on ice hockey in literary fiction for example, sociologist Cara Hedley has indicated that the term "bubs" in the context of ice hockey in Canada, is a common reference to a part of the female anatomy and is therefore "a seed of hockey's exclusionary mythology: the hockey world that ... is a boys' only club" and that "these narrow parameters of inclusion also extend to the version of masculinity defining the population of this world". 40 Thus, 'Bubs' Britton an all-Canadian football and ice hockey player, in terms of modern-day terminology was an early 20th century "jock" - an identity which developed "out of the experience of participation in high-profile, high-status sports for which some degree of structured physical violence and intensive, hegemonically masculine imagery are hallmarks" and which are positively identified with masculine norms such as winning and playing through pain. ${ }^{41}$

With six players to a team, the number of attendees was sufficient to field at least eight teams. Optimising their presence, the meeting agreed to the formation of four clubs: Old Edwardians with the alumni of King Edward VII School as its target membership; Municipals (an existing sport and recreation club for municipal employees in blue-collar and managerial positions); Wanderers (a social club for the English-speaking elite including businessmen, professional and civil servants in the city with an established sports reputation); 42 and Mohawks, with its Canadian character.

The first three clubs were all established entities with a significant history of involvement in sporting activity and a broad (though "whites-only") membership base spread over a number of sports including rugby, tennis, soccer, horse-racing, athletics, cycling and cricket. When the South African Ice Hockey Association (SAIHA) was established on 20 July 1936, these clubs also became the first affiliates of the new body, and were joined by a new club, named Maple Leafs with a (white) membership of men who were reportedly employed "in and around the city". ${ }^{43}$ The naming of two of the clubs, Maple Leafs and Mohawks, was especially significant since their identities were appropriated from two similarly-named and famous clubs in Canada, the game's most significant centre. This can be seen as consistent with sport

39. N.N. Bobyreva, "Nicknames in the Sport Society: Lingvocultural Aspects", AD ALTAJournal of Interdisciplinary Research 7, 2, 2017, p 229.

40. C. Hedley, "The Myth of Hockey and Identity in Paul Quarrington's King Leary", available online at https://read.aupress.ca/read/writing-the-body-inmotion/section/99d09778-ab2c-43e0-89a4-7e36a62f922d (Accessed 10 September 2020).

41. K.E. Miller, "Sport-related Identities and the "Toxic Jock”", Journal of Sport Behavior 32, 1, 2009, p 73.

42. T. Gutsche, Old Gold: The History of the Wanderers Club (Howard Timmins, Cape Town, 1966).

43. "New Field Anticipated for Canadian Hockey Players", Evening Citizen (Ottawa), 9 December 1936, p 10. 
sociologist and historian John Nauright's contention (made in a different context), that the act of naming of teams extends beyond mere social and "cultural mimicking" and indeed forms part of a complex and "elaborate process of proving respectability". 44

In terms of the distribution of players, those of Canadian ancestry gravitated towards the Mohawks and Maple Leafs clubs, following an earlier decision that the first-mentioned would consist of "experienced players". ${ }^{45}$ While some of these individuals came to South Africa during the gold rush of the 1880s, a significant number remained in the country in the aftermath of the Anglo-Boer War (South African War). In the latter ranks were some who were formerly entrepreneurs, office workers, blue-collar workers and tradesmen, while others were unemployed or were simply fortune-seekers. ${ }^{46}$ Given the socially exclusive nature of Old Edwardians and accessibility to only those who had graduated from the school, the consensus among the members of the founding conference according to the Morning Bulletin newspaper, was that it [as the third team] would field "continental players" (i.e. those born in Europe) with the remaining club accommodating locally-born players and new entrants to the game. ${ }^{47}$ It was also hoped to recruit members of the South African Air Force to form a team. SAIHA's founders were thus clearly intent on maintaining their links with their homeland but also on ensuring immediate competitiveness.

The establishment of ice hockey in Johannesburg on the eve of the Empire Exhibition was therefore far from an accidental affair. Its founding was a positive development that was welcomed in Canada, the "spiritual heartland of the game". ${ }^{48}$ That country had made consistent attempts to "assert a national identity and a prominent place", as a self-governing dominion "within the British imperial family of nations", and since the 1924-1925 Exhibition, had also endeavoured to export its indigenous sports, such as lacrosse, to other parts of the world". 49 The significant involvement of several Canadians, especially James Britton, in the setting-up of the sport in the run-up to the exhibition, presented their country with an opportunity to promote its national cause and within this context, to use sport as a "soft power" to achieve its stated objectives. ${ }^{50}$

44. J. Nauright, Sport, Cultures, and Identities in South Africa (David Philip, Claremont, 1998), p 62.

45. "Ice hockey Association is started on Rand", Rand Daily Mail, 14 July 1936, p 19.

46. C. Miller, "A Preliminary Analysis of the Socio-economic Composition of Canada's South African War Contingents." Histoire sociale/Social History, 8, 16, 1975.

47. "Ice Hockey Finds a New Home", Morning Bulletin, 17 October 1936, p 15.

48. “Royal Six May Play in 'World Ice Series'”, Montreal Gazette, 13 February 1936, p 13.

49. Clendinning, "Exhibiting a Nation", p 79.

50. In other words, to use sport as a tool of image-building; a platform for dialogue, trustbuilding and integration rather than persuasion. See H.M. Nygård, and S. Gates. "Soft Power at Home and Abroad: Sport Diplomacy, Politics and Peacebuilding", International Area Studies Review, 16, 3, 2013, p 236. 
The new arena, which was located opposite the Johannesburg railway station and within walking distance from the central business district, was also easily accessible by train and tram. It boasted the latest ice-making technology provided and maintained by Enoch \& Co. Ltd of London which used high-pressure imported anhydrous ammonia imported from Europe in large steel bottles "which are passed into a large storage cylinder". Further, "the gas given off is drawn from this cylinder into one or more compressors (three), each of which is driven by a 60 h.p. electric motor" etc. This was followed by an intricate process of condensation, cooling, circulation, distribution and freezing. After each skating session, the rink floor was swept and re-frozen to ensure a consistently smooth surface. ${ }^{51}$

On 19 September 1936, with the opening of the Empire Exhibition Rink in Milner Park, the two university teams representing Oxford and Cambridge fielded eleven Canadians, four British, one German and six Americans. The crowd, noted the Glasgow Herald, was "spellbound" during the first period of play and even forgot to cheer on the teams. They were implored "to make some noise" to inspire the players in the arena. ${ }^{52}$ Three days later, the organisers, having appropriated the green and gold colours of national South African sport for monetary purposes, fielded team South Africa in its debut "test" against Oxford University. ${ }^{53}$ The eleven-member squad consisted entirely of white immigrant players. The South Africans lost narrowly (5-7). These events provided a useful platform for the launch of a domestic league under the SAIHA.

The SAIHA'S inaugural season started in October 1936 with only three clubs, the Johannesburg Lions, the Maple Leafs and the Mohawks in its senior competition. Of the original founding clubs, the Old Edwardians failed to enter the senior competition for lack of competitiveness, while Municipals refrained from participation probably because of lack of experience in the game. The Old Edwardians club, however, entered the Junior League together with the Proteas, the University of the Witwatersrand, the Old Johannians, the Old Parktonians, and two more secondteams from the senior clubs. ${ }^{54}$ The Johannesburg Lions club, which had been formed during the time between the founding of the SAIHA and the start of the Empire Exhibition, attracted a good number of quality players, including Heinz Ball, an experienced former German international player. The matches between the Maple Leafs and the Mohawks introduced an element of historical rivalry into the

51. Johannesburg Ice Skating Company, Souvenir of the Opening of "Niagara", Johannesburg, 4 November 1911.

52. Glasgow Herald, 22 September 1936, p 8.

53. The colours green and gold were first adopted as South Africa's national colours in 1903 by the South African Rugby Football Board for its national team, the "Springboks" prior to its tour of the British Isles in 1906. Following the success of the national rugby team in this and subsequent tours and matches, the colours were adopted as the representative colours for all South African sports.

54. "New Field Anticipated for Canadian Hockey Players", Evening Citizen, 9 December 1936, p 10. 
Johannesburg arena with their prominent Canadian character because of the strong presence of former McGill and Queens University alumni. In the words of S.L. Lorenz, a leading historian on masculine rivalry in Canadian ice hockey, the Johannesburg ice arena was transformed into an extra-territorial site for the continued battle of domestic Canadian hockey clubs to build "narratives of regional identity, civic boosterism, and community rivalry".55 The presence of seasoned European internationals added an extra edge to proceedings. At season's end in December 1936, the Mohawks finished as the winner of the Exhibition Trophy, the Maple Leaf team was the inaugural Dorfman Cupholder, the Old Edwardians the Anderson Cup champion team and the Johannesburg Lions, became the holders of the Mansell Cup. This outcome and the prestige of having won one or the other of the championship trophies at stake, gave everybody a real boost and sufficient incentive to continue their involvement in the next season.

By December 1936 and following the conclusion of the first South African season, the Canadian newspaper, the Drummondville Spokesman, reported the existence of a formal relationship or "articles of alliance" between the Canadian Amateur Hockey Association and its South African counterpart. ${ }^{56}$ This announcement and the possibility of a future competitive arrangement between the two bodies was widely welcomed since it offered Canadian players new playing opportunities at a time that the country's relationship with its European counterparts was under strain. $^{57}$ As Mark Dyreson explains, it simultaneously offered expatriates an opportunity to combine, "displaying [their] national prowess with telling stories about themselves to their fellow citizens and global audiences". ${ }^{5}$

This potential friendly relationship and the possibility of further international competition was an exciting development for the SAIHA, especially after the association gained membership of the International Ice Hockey Federation (IIHF) on 17 February 1937. However, it could not save the Empire Rink at the same time because this rink had seemingly been constructed specifically for the purposes of the Empire Exhibition and was not designated to serve any further purpose. In addition, the new sport still had to build a loyal and paying fan base and a pool of new players had to be recruited. Furthermore, the rink had to import the necessary [and very expensive] equipment needed. The demise of the rink left the clubs without a suitable arena. ${ }^{59}$

55. S.L. Lorenz, "Manhood, Rivalry, and the Creation of a Canadian 'Hockey World': Media Coverage of Early Stanley Cup Hockey Challenges, 1894-1907", PhD thesis, University of Alberta, Edmonton, Canada, 2012.

56. Drummondville Spokesman, 17 December 1936, p 17.

57. Evening Citizen, 9 December 1936, p 2.

58. M. Dyreson, "Globalizing the Nation-Making Process: Modern Sport in World History", International Journal of the History of Sport, 20, 1, 2003, p 93.

59. Nordmark, "Ice Hockey in South Africa". 


\section{Ice hockey entrepreneurship and sporting identity before apartheid, 1937 to 1948}

In January 1937, the Empire Rink changed ownership. After its purchase by the Union Ice Rink Limited the company directors were Colin Charlewood Frye, who was chairman of the Empire Exhibition (South Africa) Limited; Joseph Dorfman, the chairman of Wembley Promotions (Proprietary) Limited; Alfred Cecil Turner and Percy Alexander Leon. With plans to lease additional land, Union Ice Rink Limited planned to "erect a magnificent building" and sports arena that would host incomegenerating events with unobstructed seating, a restaurant, lounge, and special facilities such as change rooms and a retail shop for club members. To achieve these plans, they closed the existing facility for six months which left the SAIHA without a playing venue and effectively stopped the nascent sport for a time.

The new facility, now renamed the Union Ice Rank, opened in June 1937 with Heinz Ball as its manager. This allowed the SAIHA to re-activate its suspended operations and re-launch the existing competitions. Intent on ensuring the facility's economic survival, the Union Ice Rank Limited, in cooperation with SAIHA, contracted the Austrian Weiner EV Ice Hockey Club for a six-week, eight-match tour of South Africa (from 24 June to 14 July). Weiner was not only one of the top clubs in the Austrian ice hockey league but was also a regular contributor of players to the national team for both the world championship and Olympic Games. This tour was a mutually beneficial undertaking, and provided the nascent sport with an important opportunity to establish firm roots at last and grow into a robust national sport.

As a business venture intent on generating profit, the organisers' focus was on attracting paying customers who were already acquainted with the game, including the membership of the various social clubs the ice hockey clubs were associated with. In addition, they advertised regularly in the Rand Daily Mail newspaper whose various editions carried regular match reports from the sport's inception. Broadening the game and attracting black participants was seemingly never on the agenda - a situation common to most other whites-only sports bodies in the country at the time.

Despite its status as a club team comprising players from Weiner EV (nine members), EK Engelmann Wien (two) and SC Hakoah Vienna, the sporting tourists played all their games against South Africa (five games or "tests") and one game against the team Johannesburg Select, as representing Austria. Only the games against the Maple Leafs, the Mohawks and one against Johannesburg Select were played under the banner of Wiener EV. ${ }^{60}$ This move was a marketing ploy that capitalised on the fact that the majority of the team's members were former national and international players who had represented Austria at the 1936 Winter Olympics. ${ }^{61}$

60. Nordmark, "Ice Hockey in South Africa".

61. See for example, Sports Reference LLC, "Hans Tatzer, Olympic Stats", HockeyReference: Olympics: Athletes, available from https://aws.hockeyreference.com/olympics/athletes/ hans-tatzer-1 and "Fritz Demmer, Olympic Stats", 
Similarly, SAIHA's fielding of select sides or combinations was designed to test players who were not scheduled to meet the visitors in any other game and to allow them to compete for a place in the "national" team. Otherwise, the South African team fielded a tested combination of players who had also played against Oxford and Cambridge. With groups of experienced players on both sides, the tour matches were keenly contested. As a result, crowd attendance of 2500 (which was the maximum seating possible) was achieved on two occasions. The test series was finely balanced and after three matches, each side had scored one victory and a draw. A second victory for the visitors set up a crucially important final match. However, this final match proved to be a disappointment since it had to be shortened because the visitors needed to begin their return journey to Cape Town. This meant that the Austrians, won the series which also concluded the first South African season.

The 1938/1939 season proved equally eventful. For a start, the senior league was enlarged from three to five clubs with the addition of Old Parktonians and University of the Witwatersrand which improved the competition's attractiveness. This experiment, however, did not work for lack of competitiveness on the part of the new entrants. ${ }^{62}$ At stake was not only the popularity of the game but also the survival of the mutually-beneficial agreement between the rink owners and the SAIHA - with two months of the existing season still to be played. Consequently, a proposal was tabled by the organisation's national leadership for the creation of four new teams (with new identities, namely Rangers, Black Hawks, the Bruins and the Red Wings) of equal strength from a pool of 36 players to involve them in the playing of a series of "all-star public exhibition matches" until May. According to Jack Khan, the secretary of the SAIHA, this proposal was an initiative to provide the public with "some really good ice hockey" and to "permit various men to play each other", to learn more about the sport and overall, to enhance the competitiveness of the whole league (junior and senior) and future national teams. ${ }^{63}$

Notwithstanding this, a minority of the clubs (both junior and senior) such as Old Edwardians and Old Parktonians, objected to the proposed creation of new teams. In addition to anxiety about losing their sporting identity, they complained of various matters including a general neglect by the national body; having a minimal say in the running of SAIHA affairs; the lack of coaching facilities; and difficulties with the procurement of playing kit and equipment. ${ }^{64}$ They threatened to withdraw rather than lose their identity. ${ }^{65}$ Most of the clubs, however, supported the initiative, which was implemented for a limited time (two months) before the start of the regular season in May 1939. This move assisted the SAIHA and its business partners to

Hockey-Reference: Olympics: Athletes. Available from https://www.hockeyreference.com/olympics/athletes/fritz-demmer-1 Accessed 30 June 2020.

62. "Drastic Ice Hockey Reorganisation", Rand Daily Mail, 18 March 1939, p 1.

63. H. Carruthers, "Four Teams for Ice Hockey Exhibitions", Rand Daily Mail, 7 March 1939, p 16.

64. “Drastic Ice Hockey Reorganisation”, Rand Daily Mail, 18 March 1939, p 1.

65. “Edwardians Protest”, Rand Daily Mail, 7 March 1939, p 16. 
maintain momentum right up to the outbreak of the Second World War. Against the background of a mass war recruitment campaign which affected most sports including rugby, soccer, cricket and baseball, Mohawks became the last regular prewar ice hockey league champion.

Faced with a shortage of active members that war service brought about, the SAIHA executive committee led by J.C. Stevens (president) and Jack Khan (secretary) and the directors of the Union Ice Rink attempted to keep interest alive by hosting of a four-team war league consisting of irregular games featuring the Maple Leafs, the Johannesburg Lions, the Mohawks, and Wits University in the 1940-1941 season. This periodic activity continued throughout the war and enabled the rapid revival of formal competition by the last quarter of 1945 . As was the case elsewhere, including in Canada, the war league also served as a means to tie serving players "to home and reminded civilians of a better, peaceful time". ${ }^{66}$ It further served as a transitional period for the South African game during which experienced players, and those who were older could disappear voluntarily from the scene to make way for new talent. ${ }^{67}$

In the early months of 1946, ice hockey slowly returned to South Africa with the hosting of occasional matches such as the Mohawks versus the "Rest" - a select combination of the available players from other clubs. Billed as a grand challenge match, this event, which was played at the Olympia Ice Rink in Johannesburg, was a fundraising event. ${ }^{68}$ The opening of the regular season in September saw only four teams (Mohawks, Lions, Tigers and University) returning to the arena. With a good number of new faces and the return of some of the former personalities, the season got underway. Mohawks, the defending champions and a club which had benefited significantly from the war league, was the first to return to its original sporting form and defended its title successfully. This aided the league's further re-establishment and consolidation on the eve of apartheid.

\section{From apartheid to isolation}

Following its narrow electoral victory in 1948, the National Party institutionalised and expanded existing racial segregation through the promulgation of a suite of restrictive laws. Although no specific legislation was passed to formalise segregated sport, the Reservation of Separate Amenities Act 49 of 1953 which legalised the racial segregation of public premises, vehicles and services, left black sportspeople in general with the poorest facilities and restricted them to separate neighbourhoods. The right to represent South Africa internationally was also explicitly reserved for white athletes by the establishment's sports federations. The ice hockey fraternity was not immune to these developments.

66. G.S. Panunto, "For Club or Country? Hockey in Wartime Canada, 1939-1945", MA thesis, Carleton University, Ottawa, Canada, July 2000.

67. “14 Goals in Ice Hockey”, Rand Daily Mail, 14 April 1939, p 16.

68. “Olympia Ice Rink - Ice Hockey”, Advertisement, Rand Daily Mail, 1 May 1946, p 4. 
Even as preparations for the 1948 Summer Olympic Games were underway, the SAIHA, which continued to be administered by a combination of businessmen and bona fide part-time players and administrators, discussed the possibility of sending a team to the 1952 Winter Olympics. Its domestic competition, therefore, became a crucial building block in this process. With only four senior clubs, no national footprint, little growth in player numbers and a general lack of international competition for at least a decade since the so-called Austrian tour, the process of preparing an Olympic team was a challenging affair.

Hamstrung by limited finances, non-membership of the SAOCEGA and not in good standing with the IIHF, no team was sent. Continued non-payment of membership fees to the IIHF also sabotaged an attempt to host the Dutch national team in South Africa, an event that was to form part of the Van Riebeeck Sports Festival which was scheduled for April 1952 to celebrate 300 years of Dutch colonialism in South Africa. The inclusion of ice hockey, in turn, was to form part of the festival organisers' attempt to portray the role of amateur sport in the building of a "nation". 69

The main festival in April and the boycott launched by dissatisfied black South Africans was followed two months later, by the African National Congress (ANC)-led Defiance of Unjust Laws Campaign. Known widely as the Defiance Campaign, this was a civil disobedience initiative involving many groups and individuals, black and white, aimed at eliminating apartheid. The National Party government reacted to suppress the unrest with brutal force using physical assaults, arrests, imprisonment and banning of many activists. Notable political figures such as Nobel Prize winner Chief Albert Luthuli of the African National Congress, the American civil rights activist, Dr Martin Luther-King Jr, and Anglican priest Father Trevor Huddleston called for the total isolation of the apartheid state. Huddleston urged that South Africa be isolated in the cultural and sports terrain in particular, to make white athletes aware that "you can't play with a straight bat if you have no opponents". ${ }^{70}$

Deprived of international participation by its organisational deficiencies, the SAIHA arranged for several special games featuring various South African select sides and overseas "all-star" teams, a widely adopted method used internationally to maintain player interest and reward consistent performers for their efforts. ${ }^{71}$ Such initiatives were also common in South Africa's other sports such as rugby and cricket. Played in between the scheduled matches for the 1953 domestic championships, the overseas-born team could select from a significant pool of former international players (both local and foreign-born naturalised citizens) to provide an incentive for the player to remain in the game. Importantly, these extra games which were

69. KAB, A709:141, “Van Riebeeck Festival, 1952”, Newspaper Cuttings, Volume IV: 16 November 1951; KAB; A709:141, 31 December 1951, "Festival of South African Sports - All Tastes Catered For", The Recorder, 16 November 1951.

70. T. Huddleston, Naught for your Comfort (Collins, Glasgow, 1956), p 150.

71. Rand Daily Mail, “Drastic Ice Hockey Reorganisation”, 18 March 1939, p 1. 
additional to the normal competition, assisted the organisers to generate additional income.

Despite open repression, black South African sports administrators such as Dennis Brutus and Milo Pillay continued with their struggle for equality and several sporting bodies cooperated to establish the Coordinating Committee for International Recognition (CCIR) in 1955 to reverse the exclusion of blacks from South African national teams scheduled for participation on international level. The CCIR also positioned itself to lobby for international recognition for black athletes and to ensure better campaign coordination and coherence amongst the national black sporting bodies. This initiative coincided with the adoption of the Freedom Charter by the Congress Alliance ${ }^{72}$ which demanded the abolition of the colour bar in cultural life, sport and education. ${ }^{73}$ As an emancipatory document, it also politicised sport and linked the struggle for non-racial and equal sporting opportunity to political liberation. ${ }^{74}$

Against this background, the SAIHA hosted the visiting crew of the Canadian cruiser HMCS Quebec who played an exhibition game in Johannesburg. Hosted by the local Navy League, the visitors also played softball and baseball. ${ }^{75}$ The South African team won the ice hockey game, which was billed as a test, by 15-0. The SAIHA yet again, however, and with an entry-deadline of 10 November 1955, failed to pay its annual subscription to the IIHF which was a prerequisite for entry into the Winter Olympics of $1956.7^{76}$ This was a double blow since the Winter Olympics in Italy also doubled as the 23rd World Championship. Not being a member in good standing further denied South Africa the opportunity to play against other full members of the world body, with serious financial implications for the SAIHA and its partners, Union Ice Rink Limited, who depended on high-profile stars to fill seats and make money.

In 1956, the Olympic year, the centre of ice hockey in South Africa shifted to Natal. This followed the opening of a new rink, the municipal Durban Ice Drome in December 1955 following the disruption of the Transvaal league in the wake of the transfer of the Union Ice Rink's ownership. ${ }^{77}$ The establishment of four clubs (Tomahawks, Tech Rangers, Mohawks, and Bears) who were organised as the Natal Ice Hockey Association provided the SAIHA with only its second affiliate. The Natal body was soon joined by the Transvaal players. Despite the challenge of long-distance

72. The Congress Alliance consisted of the following political organisations: ANC, SA Indian Congress, SA Coloured People's Congress and the Congress of Democrats.

73. University of the Witwatersrand, Historical Papers Research Archive (hereafter UWHPRA), Congress of the People, The Freedom Charter, Johannesburg, Collection Number AD 1137: Federation of South African Women, 1954-1963.

74. R. Suttner, "Talking to the Ancestors: National Heritage, the Freedom Charter and Nation-Building in South Africa in 2005", Development Southern Africa, 23, 1, March 2006, pp 6-8.

75. Quebec Chronicle-Telegraph, 26 March 1955, p 3.

76. "Plans for Olympics", Mirror (Perth), 25 June 1955, p 20.

77. Nordmark, "Ice Hockey in South Africa". 
commuting, the enlargement of the Natal league kept the sport alive and enabled a return to the hosting of representative games. The first interprovincial match featuring Natal and Transvaal, was played on 5 October 1957. However, as yet there was no progress at all on the participation in the sport of black players or of women.

Following the re-opening of the Wembley Ice Rank (the former Union Rink) in Johannesburg, ice hockey restarted in Transvaal in September 1958 with only three clubs, Lions, Wolves and Tigers. With seven clubs in two provinces, it was time to reorganise the SAIHC and to elect new office bearers. Consequently, Tommy Durling, a Canadian, was elected as president in place of Joseph Conrad, who had held the position since 1952 .

This transition of office intersected with the establishment of the Campaign Against Race Discrimination in Sport in Britain in October 1958 to spearhead opposition to all-white tours. This event was followed by the founding of the South African Sports Association (SASA) in 1959, an activist organisation working towards the achievement of equality for black athletes. However, after it failed to convince its white counterparts of the importance of terminating apartheid in its operations and persuade corporate sponsors to withdraw their financial support from racist sports bodies, it started to lobby international controlling sports federations in the hope of forcing change. ${ }^{78}$ SASA motivated its demands by insisting that not only was practising racism contrary to the Olympic Charter, but hosting and participating in race-based tours was tantamount to assisting in the "importation of racialism". ${ }^{79}$

On 21 March 1960, at Sharpeville about $50 \mathrm{kms}$ from Johannesburg, during a protest action against passes required for the movement of black South Africans, the police killed 69 demonstrators. In anticipation of a violent reaction from antiapartheid political organisations, including the ANC, South African Communist Party and Pan Africanist Congress, the South African government outlawed all these liberation movements. Under the subsequent state of emergency, anti-apartheid opposition was strongly repressed and a significant number of activists were driven into exile. Following the events at Sharpeville, the international anti-apartheid movement intensified its campaign against segregated sport. ${ }^{80}$

The International Olympic Committee faced numerous appeals from what historian Scarlett Cornelissen terms a "hybrid collection of transnational advocacy

78. UWHPRA; South African Institute of Race Relations Collection (hereafter SAIRR), AD 1715: D.A. Brutus of South African Sports Association, "Appeal to All Olympic Councils", dated 1 January 1962; and UWHPRA; SAIRR, AD 1715: D.A. Brutus (South African Sports Association) - The Manager, Hullett's Sugar Refinery, 16 July 1962.

79. UWHPRA; SAIRR, 1892-1974: Collection Number: AD1715 - South African Sports Association: "Memorandum - Minutes and Proceedings", Saturday 10 January and Sunday 11 January 1959.

80. C. de Broglio, 'The SANROC Story', 23 February 2015. Available online at http://onlinelaw.co.za/ docs/The SANROC story.pdf. Accessed 13 December 2016. 
networks", but chose to defy widespread international opinion and the call for South Africa's isolation, ${ }^{81}$ and allowed four South African speed skaters to participate in the Winter Olympics at Squaw Valley in the United States in 1960. Due to almost two years of intermittent activity, the SAIHA failed once again to send a team to this important event. Unfazed, the leadership of the organisation - which comprised Tommy Durling (president) Ronnie Davis (vice-chairman) Eric Sellers (secretary) and the treasurer Michael Viljoen - shifted their planning towards the World Championships the following year. When the ice hockey "Springboks", finally made it to the World Championships in Switzerland in March 1961, they did so against the background of increased global anti-apartheid activity.

Given the evolving nature of the global anti-apartheid movement, and the continued "search for a much larger, multi-textured effort to achieve far-reaching alterations", as Indian anti-apartheid activist Enuga Reddy terms it, a general boycott of apartheid sport was still in the future. ${ }^{82}$ Instead, larger political issues dominated the ice hockey World Championship: these included, in the face of opposition from West Germany, the recognition of East Germany as a sovereign state by the Eastern Bloc countries (such as Romania and Yugoslavia) and by the International Ice Hockey Association. ${ }^{83}$ Having gained its first world championship experience, the SAIHA entered the next phase of its development more aware of the state of the sport and its intersection with international politics, but still fully engaged in the struggle to ensure its financial sustainability.

By 1963 the SA Sport Association, which had over the intervening period evolved into the South African Non-Racial Olympic Committee (Sanroc) under the leadership of Dennis Brutus, replaced the demand for desegregation of sport and society with a call for an international boycott and the end to all segregated sport. ${ }^{84}$ It further aimed to "frustrate whites, deprive their sport of stimulus and drive down standards". 85 The reasoning behind this tactic was the hope that isolation would compromise both South Africa's competitiveness and undermine its attractiveness as a sporting tours destination. Because of his political activities, Brutus was sentenced

81. S. Cornelissen, “Resolving 'the South Africa problem': Transnational Activism, Ideology and Race in the Olympic Movement, 1960-91", The International Journal of the History of Sport, 28, 1, 2011, p 153.

82. E.S. Reddy, "Cultural Boycott: Statement by Director of U.N. Centre Against Apartheid (1984)", Palestinian Campaign for the Academic and Cultural Boycott of Israel (Pacbi) Press Briefing, BDS Movement.net, 24 November 2010. Available from https://bdsmovement.net/news/cultural-boycott-statement-enuga-s-reddy-directorun-centre-against-apartheid-press-briefing. Accessed 1 March 2019.

83. J. Soares, “Cold War, Hot Ice: International Ice Hockey, 1947-1980”, Journal of Sport History, 34, 2, 2007, p 211.

84. D. Booth, "Hitting Apartheid for Six? The Politics of the South African Sports Boycott", Journal of Contemporary History, 38, 3, July 2003, p 482.

85. C. Merrett, "'In nothing else are the deprivers so deprived': South African Sport, Apartheid and Foreign Relations, 1945-1971", International Journal of the History of Sport, 13, 2, 1996, p 152. 
to 18 months imprisonment on Robben Island, apartheid's notorious island prison, which severely curtailed the activities of SASA.

However, thanks to the collective effort of a range of organisations such as the London Anti-Apartheid Movement and the Defence and Aid Fund, a Sanroc Committee was established in the United Kingdom which internationalised the international sports' struggle and allowed the anti-apartheid network to initiate what Olympic historian Jules Boykoff terms a campaign of "brass knuckle nation-state pressure". ${ }^{86}$ Assisted by the African bloc and the Soviet Union within the IOC, they succeeded in securing South Africa's exclusion from the 1964 Olympic Games in Tokyo. Notwithstanding this, the local leagues continued with an eye to sending a national team to the second World Championship which was scheduled for Yugoslavia in 1966.

Like its predecessor in 1961, the Springbok team entered the ice rink illprepared as a result of a lack of incoming tours. In addition, the domestic game showed little growth and was still restricted to the Transvaal and Natal. The Springboks, unsurprisingly, lost all four matches played against Italy and Denmark (two against each), save for winning the Fair Play Trophy. With increased calls for South Africa's exclusion from international sport, it was back to the drawing board for the SAIHA.

\section{Semi-professionalism, 1967-1980}

In 1967, the Union Ice Rink changed ownership yet again. As had become the standard practice, the new owner of the renamed facility (now the Wembley Ice Rink), Hymie Sofer, a Johannesburg-based billionaire, businessman and bookmaker, was duly elected to the presidency of the SAIHA. Concomitantly, a new competition for the Sofer Bowl was inaugurated. In the background, and under pressure from its membership, the IOC withdrew its invitation to South Africa to participate in the 1968 Olympic Games. With that, any chance for its ice hockey team to participate in the next Winter Olympics became an impossibility. Against this background and with due consideration to their business objectives, the SAIHA opted for a programme of semi-professionalisation to ensure the financial sustainability of the rink and league. Further, the SAIHA embarked on a player recruitment programme to benefit the four clubs: the Swiss Bears, Wembley Lions, Southern Suburbs and Edelweiss.

Among the first batch of imported players were Austrian internationals Walter Brandstatter and Heinz Knoflach, the Swedish player Tommy Sahlsten, Canadians Billy le Page, Dave Park and Doug Scott, and Swiss players, Jurg Zimmermann and Peter Casulta. They were all allocated to the existing affiliates. Given the still evolving

86. J. Boykoff, "Protest, Activism, and the Olympic Games: An Overview of Key Issues and Iconic Moments", The International Journal of the History of Sport, 34, 3 and 4, 2017, p 168. 
character of the anti-apartheid boycott movement and the continued existence of significant gaps in the global network, for the most part their presence in South Africa went unnoticed. The Austrian Anti-Apartheid Movement (Osterreich Anti-Apartheid Bewegung) for example, only came into being in 1977. Prior to this, the country maintained full diplomatic ties and trade relations with South Africa. ${ }^{87}$

In turn, Canada opposed apartheid but did not support the imposition of punitive economic and financial sanctions to force change. It supported South Africa's continued membership of all international organisations while simultaneously supporting the anti-apartheid opposition. Officially, it was stated that Canada discouraged "sporting contact with South Africa by refusing both moral and financial aid to individuals or teams competing in South Africa and to any sporting event held in Canada in which South Africans participate". ${ }^{88}$ Its citizens continued their visits to South Africa and their interaction with the apartheid state. For the ice hockey sportsmen, playing in South Africa during the European summer represented both an income-generating opportunity and a holiday. To offset the cost of their contracts, club owners and their network of associates offered accommodation, part-time work, paid travel and match fees - a situation that according to one player amounted to being on a "hockey safari". 89

Against this background, the Swiss Bears retained the league title they had captured the previous season. They also won the Sofer Bowl after defeating the Johannesburg Southern Suburbs team in the final match. To complete the season, the SAIHA hosted the German Eintracht Club for a three-match tour during September 1967. In the opening match and a contest aimed at testing the strength of the domestic league, the visitors played and lost against double-champions, Swiss Bears (by 10 goals to 4), followed by two matches ("tests") against a South African all-stars team. The hosts won by 5-4 and 8-3, respectively, to crown a sporting year described by the Rand Daily Mail as one in which "a new Everest has been reached". 90

The creation of an exotic league based on a core group of seasoned overseas players playing alongside the local teams, almost immediately increased the number of paying fans. To boost further interest, the SAIHA invited the Dusseldorf Ice Hockey Club to tour South Africa in October 1968. Profit-making in the absence of official international competition, therefore, continued to be the prime motive. This

87. W. Sauer, "Austria and South Africa during Apartheid", in South African Democracy Education Trust, The Road to Democracy in South Africa, Volume 3: International Solidarity, Part I (Unisa Press, Pretoria 2008), pp 630-640.

88. B.D. Tennyson, “Canadian Policy towards South Africa”, Africa Today, 29, 1, 1982, pp 5-6.

89. M. Merk, "Days of Safari Hockey Gone: When Maple Leafs and Swiss Bears Ruled in South Africa", International Hockey Federation, 2010 online at http://www.iihf.com/home-ofhockey/news/newssingleview/?tx ttnews\%5Btt news\%5D=4771\&cHash=c4e72414 773b3f8afce9054277578279 Accessed 18 September 2017.

90. The 1967 South African Sports Annual (Rand Daily Mail, Johannesburg), pp 11, 136. 
approach, in other words the invitation of private, professional clubs, was continued under the leadership of Otto Hertz, a wealthy garage workshop and car rentals owner who replaced Sofer as the SAIHA president in 1970.

The Dusseldorf tour of four matches (20 September to 3 October 1968), sponsored jointly by Pepsi Cola and Lufthansa, included a match against a Canadian invitation team of players in the domestic league, one against the national league champion and two against a South African all-star team. This combination and the involvement of a so-called national team, was aimed at filling seats and deriving profit. ${ }^{91}$ According to reports in the Rand Daily Mail, these contests offered much excitement, drama and aggression because they were "full of incidents ... players were send sliding across the ice from trips and two received medical attention" following some 'stickwork' against each other". ${ }^{92}$ This drama was further punctuated by "steady traffic to and from the 'cooler', frequent disputes with the referees, threats to walk-off the court and frequent send-offs". The hallmark of undiluted excitement kept the paying customer happy and enhanced the sport's general image as one for the tough and the brave. Although the Germans won all the matches, it was a tour that satisfied the organisers. ${ }^{93}$

Players such as Swiss internationals Jakob Kölliker and Guido Lindemann and Finnish player Timo Lahtinen, also joined the league. Although professionalisation based on imported players left very little space for the broadening of the sport beyond the elite of the white community, it assisted in the creation of a more balanced sporting domestic league. The period from 1968 to 1970, therefore, saw the league title changing hands regularly in line with the competitive balance between clubs. Swiss Bears, the champions in 1968, were replaced by the Canadian Hush Puppies and the Maple Leafs in subsequent years.

Even so, several factors retarded the full professionalisation of the domestic league. Despite the beneficial nature of the "hockey safari" provided for foreign players, disputes arose about conditions of service such as for travel, residence and pay. In July 1970, five Durban-based Canadian players were accused of a breach of contract for terminating a four-month contract prematurely, following a dispute about their service conditions. ${ }^{94}$ The SAIHA, claiming a breach of contract, fraud and financial loss of R12 507 (\$18 170), secured an urgent order from a judge in chambers for the arrest of these players and their detention by the police - an act which resulted in an irreparable breach of trust.

91. N. Leck, “Dusseldorf to Make Ice Hockey Tour”, Rand Daily Mail, 23 July 1968, p 25.

92. “A Hot Night on Wembley Ice", Rand Daily Mail, 25 September 1969, p 15.

93. “Dusseldorf Threatens Walk-Off”, Rand Daily Mail, 4 October 1968, p 27.

94. Ottawa Citizen, 13 July 1970, p 11. 
Against the background of the intensifying international sports boycott campaign, threats of blacklisting certain athletes and artists and the weakening of the South African currency, the erstwhile lucrative summer safaris lost their attractiveness for foreign players. Almost immediately this impacted on the competitiveness and profitability of the domestic league, which lost its ability for further growth. No more than four clubs were active at any given time. Unsurprisingly, the number of spectators remained low, and dwindled even further after the introduction of television and the live broadcasting of other sport events. The business of both hockey administration and the continued financial viability of ice rinks as a source of long-term investment, now faced a severe threat. 95

\section{Race, fans, finances and politics, 1975-1977}

With the promulgation of the Separate Amenities Act 49 of 1953, mixed-race audiences at sports events were forbidden, which impacted negatively on venues that white entrepreneurs owned. Although some promoters wanted to host multiracial audiences, most public indoor venues were too small for the installation of segregated seating. This meant that event organisers used open-air venues, a situation which was wholly impractical for ice hockey.

Promoters had to negotiate with the Department of Community Development (DCD) established in July 1961, for permission to open events to all races. ${ }^{96}$ Such applications were frequently delayed, permission withheld, or events even cancelled at the last minute. Even hosting events at fit-for-purpose venues with separate entrances for the different groups, was no guarantee that approval would be granted. ${ }^{97}$ This left promoters, athletes and fans frustrated. Signs of a shift in policy only started to appear in late 1975 when an application by the Silverblades Ice Rank in Cape Town, requesting permission to admit (to a maximum number of 300) people designated as "Coloureds", as well as to reserve two nights per week at the facility for the use of this group, was granted. ${ }^{98}$

The prospect of bankruptcy forced rink owners to submit permit applications to the DCD. Some, such as the owners of the Silverblades Ice Rink, tried to circumvent

95. KAB; Dept Community Development (hereafter DCD), 434:32/1/4584/162:5935, S. Peltz (ICECAP Propriety Ltd.) - The Regional Representative: DCD, 28 December 1972.

96. The mandate of this department in terms of Proclamation 34 of the Group Areas Amendment Act (No. 23) of 1961 was inter alia to manage the administration associated with the Group Areas Board inclusive of permit applications, to develop local government by Coloured and Asian people in their group areas, socio-economic development of group areas and oversight over the provision of public amenities by the responsible municipalities.

97. Cape Argus, 21 November 1967.

98. KAB, DCD, 434:32/1/4584/162:61, Herbert Buhrer, Secretary/Treasurer, Western Province Ice Hockey Association - The DCD, 3 March 1975. 
the regulation by applying for permission to admit mixed-race (as opposed to those classified as Bantu or African) patrons to shows, to make a profit. ${ }^{99}$ Applications to accommodate black (black, coloured, and Indian) patrons on separate evenings as well as entry to league, cup, inter-provincial and international ice hockey games were declined.100 Even attempts to remind the political decision-makers about the precarious status of South African sport failed to persuade them about the need for greater flexibility. The authorities regarded admitting people of colour to facilities located in white group areas, as too "contentious".101 The situation remained unchanged, much to the detriment of the financial health of ice rinks concerned. ${ }^{102}$

On 16 June 1976, the country saw a wave of violence following a protest march of black students against political exclusion and inferior education in Soweto, Johannesburg. In continuation of a familiar pattern, a police clampdown and the declaration of a state of emergency was followed by the killing, banning, detention and exile of a significant number of people. Under the emergency regulations, mass gatherings in black areas, including sports events, were subjected to strict security controls, further complicating black access to public facilities in various areas. Given the seriousness of the events of the time, wide-ranging changes in government, including within the sporting arena, became necessary.

\section{Ice hockey and the politics of multi-racial sport, 1977-1991}

In January 1977, the South African government finally agreed to allow sports bodies to select racially mixed teams to represent the four provinces and the country. The new policy coincided with the announcement in the USA of the newly-elected Carter administration's foreign policy guidelines which, according to Cyrus Vance, the US secretary of state, were to be guided by a concern for human rights in general and southern Africa in particular.

The administration was especially committed to "speaking frankly about injustice at home and abroad" and to promoting "freedom for all people". ${ }^{103}$ Furthermore, the US vice-president, Walter Mondale was tasked with engaging the South African government about ending racial discrimination, the establishment of black majority rule and conveying America's "unalterable" opposition to apartheid. ${ }^{104}$ Anti-apartheid activists such as Peter Hain of the London-based Stop All Racist Tours

99. KAB, DCD, S. Peltz, 1972.

100. KAB, DCD, Herbert Buhrer, 1975.

101. KAB, DCD 434:32/1/4584/162:80, T.S. Meyer, Director Ice Cape (Pty.) Ltd. - The Regional Representative, DCD, 23 January 1975.

102. Central Archives Repository, Pretoria (hereafter SAB); MSO 83:MS6/5/42, Lionel G. Murray - The Honourable Minister of Sport and Recreation, 30 June 1975 and P.G.J. Koornhof - L.G. Murray MP, 11 August 1975.

103. Canberra Times, 2 February 1977, p 36.

104. Canberra Times, 19 May 1977, p 4. 
denounced the South African authorities' lifting of restrictions on racially mixed sports teams as an attempt to undermine the struggle for non-racialism. ${ }^{105}$

At home, Minister Piet Koornhof roundly denied this and maintained that the policy change was to create more opportunities for "all athletes". ${ }^{106}$ However, the international anti-apartheid movement could not stop the new policy's implementation, and in any case, it made no difference to the local ice hockey family. It continued to play its all-white leagues despite the inability to tour overseas and the 30-year absence from world championships.

Following intensive deliberations, on 15 June 1977 the Commonwealth heads of government issued the Gleneagles Agreement on Apartheid Sport, the first multilateral decision to ban South African sport on a global scale. It declared the continuation of such contact an endorsement of apartheid. This pressure was extended in July-August 1978 at the World Conference to Combat Racism and Racial Discrimination held in Geneva, where apartheid was declared a "crime against humanity and a threat to world peace".

At the same time, Bulgaria requested that the IIHF suspend South Africa's membership. The local ice hockey body responded angrily, saying that this "smacked of petty politics". 107 The leadership of the SAIHF, however, did concede that calls of this nature had serious repercussions for its project to attract overseas players. The new measures made their continued presence in the South African leagues problematic and increased the pressure on ice rink entrepreneurs. These businessmen realised the monetary potential of black support for ice hockey and increased their efforts to have the existing policy changed.

In order to mitigate the negative effect of television, which had first come to South Africa in 1976, ice rink owners applied for more concessions to admit black people. Even so, and to prevent any potential white backlash, the South African IceSkating Association limited the inclusion of "non-white" skaters to segregated clubs. New participants were restricted to the beginner's level while merit selection was only allowed up to junior national level as per agreement with the Department of Sport and Recreation. ${ }^{108}$ Mixed-race teams were not allowed, but the participation of individuals in sub-national competitions was permitted. Similarly, participation in national and medal competitions was restricted to whites.

105. Canberra Times, 2 February 1977, p 36.

106. Canberra Times, 13 August 1977, p 1.

107. Star, 27 June 1978, p 30.

108. SAB; MSO 83:MS6/5/42, Lionel G. Murray - The Honourable Minister of Sport and Recreation, 30 June 1975; and P.G.J. Koornhof - L.G. Murray M.P., 11 August 1975. 
These measures were mostly cosmetic and were justified as being the most economical ones given the high costs associated with rink construction and the legislated need to provide separate facilities for black players. ${ }^{109}$ Unsurprisingly South African teams were denied entry to at least 38 international events in that year. ${ }^{110}$ Similarly, Piet Koornhof's attempt to convince the IIHF that the sport was open to all, notwithstanding the need for a permit or legal permission to "play on any rink in South Africa or to join any club", was an abject failure. ${ }^{111}$ Instead, the South African junior ice skating team became the target of a boycott by several East European nations at the Junior International Ice Skating Competition in France in April 1979. ${ }^{112}$

The 1980s saw South Africa almost entirely excluded from the international sport arena following a spate of tour cancellations. Whereas other sports such as netball and amateur wrestling could follow a twin strategy of hosting rebel tours and establishing closer liaison with the sports arm of South Africa's politically-created ethnic enclaves, the so-called Bantustans or homelands, these options, in the absence of ice rinks in those areas, were not available to ice hockey. ${ }^{113}$ The ice hockey Springboks could not participate in the annual interstate games organised by the Southern African Federation of Interstate Games (SAFIG) which took place regularly from 1986 onwards. ${ }^{114}$

The active pursuit of rebel tours led to heightened isolationist campaigning and an increase in the number of countries that acceded to appeals for the rejection of all race-based sport and the strict application of the UN blacklist or register of sports contacts. ${ }^{115}$ Furthermore, it discouraged a significant number of international sports stars and entertainers from visiting and performing in South Africa. In June 1988, in addition to issuing a call for all international sports organisations to sever ties with South Africa, the IOC appointed a special commission to study ways of increasing the country's isolation, including the formal exclusion of athletes in breach of the international boycott. Against this background, the Finnish government prevented an ice hockey team from travelling to South Africa, confirming South Africa's ice hockey's

109. SAB; Lionel G. Murray, 1975.

110. Star, 26 March 1979, p 13.

111. SAB, Letter, MSO 83: MS6/5/42: WIR/Y5: Dr P.G.J. Koornhof - the President, Dr G. Sabetzki, 18 May 1978.

112. SAB; MSO 83:MS6/5/42, B 1/1/8: Ambassador L. Pienaar: South African Ambassador, Paris - Secretary for Foreign Affairs, Pretoria, 23 April 1979.

113. H.G. Bart (ed.), Sustagen Supersport All-Sports Annual (Classifinder, Johannesburg, 1977), p 199.

114. The SAFIG consisted of South Africa, Bophuthatswana, Venda, Transkei, Ciskei plus South West Africa (now Namibia) and hosted "national games" to provide these entities with a foothold in "international" sport.

115. Ismail Jakoet, Private Collection (Cape Town), Correspondence, South African NonRacial Olympic Committee (SANROC): Sam Ramsamy - HE Roger Bambuck, Secretary of State for Youth and Sport, "Re. Collaboration with Apartheid South Africa", 7 August 1989. 
isolation.116 This remained the situation until 20 May 1991 when the country's suspension from participation in international events and tours was finally lifted following the unbanning of anti-apartheid political organisations and the release of political leaders such as Nelson Mandela and Walter Sisulu the previous year.

\section{Conclusion}

The establishment and growth of ice hockey in South Africa was the result of the activities of both foreign-born players and ice rink entrepreneurs. Whilst the players used ice hockey as a means to accommodate to a new context, the entrepreneurs tried to derive profit from the growing public interest in all forms of ice sport, creating an unhealthy situation in that the sport was almost totally dependent on the profitability of the ice rink.

Furthermore, the SAIHA's hands-off approach from 1936 onwards as far as the national Olympic and world body was concerned, motivated by their desire to maintain full operational control over their income-generating activities, resulted in the ice hockey fraternity being denied tours and barred from entry into world events, all of which was to its financial detriment.

From the outset, ice hockey in South Africa was enmeshed in the politics of race, segregation and from 1948 onwards, institutionalised and formalised racism in the form of the apartheid system. Due to its exclusively white organisational and business character, the ice hockey fraternity failed to involve black players and administrators even when the official state policy was amended to allow for limited inter-racial mixing in the broader sports sector. Only when they suffered the financial consequences of racially exclusive audiences and direct live television broadcasts, did ice rink owners involved with the sport begin to consider admitting black players and supporters. When international doors started closing, due to its complicity in events that extended beyond mere "frivolities on ice", ice hockey suffered the same fate as other local counterparts. Its formal exclusion only ended when South Africa was readmitted to the IOC in 1992.

116. Die Burger, 4 July 1988, p 9. 


\section{REFERENCES}

Bickford-Smith, V., Ethnic Pride and Racial Prejudice in Victorian Cape Town: Group Identity and Social Practice, 1875-1902 (Cambridge University Press, Cape Town, 1995).

Bobyreva, N., "Nicknames in the Sport Society: Lingvocultural Aspects", Ad AltaJournal of Interdisciplinary Research 7, 2 (2017).

Booth, D., "Hitting Apartheid for Six? The Politics of the South African Sports Boycott", Journal of Contemporary History, 38, 3 (July 2003).

Boykoff, J., "Protest, Activism, and the Olympic Games: An Overview of Key Issues and Iconic Moments", The International Journal of the History of Sport, 34 (2017).

Britton, S., "'Come and See the Empire by the All Red Route!': Anti-imperialism and Exhibition in Interwar Britain”, History Workshop Journal, 69 (Spring 2010).

Carruthers, H., "Four Teams for Ice Hockey Exhibitions", Rand Daily Mail, 7 March 1939.

Clendinning, A., "Exhibiting a Nation: Canada at the British Empire Exhibition, 19241925", Histoire Sociale/Social History, 3, 77 (2006).

Cornelissen, S., "Resolving 'the South Africa problem': Transnational Activism, Ideology and Race in the Olympic Movement, 1960-91", The International Journal of the History of Sport, 28, 1 (January 2011).

Cubizolles, S., "Soccer in a Rugby Town: Restructuring Football in Stellenbosch", Soccer \& Society 11, 1 / 2 (2010).

De Broglio, C., "The SANROC Story", 23 February 2015, online at http://onlinelaw.co.za/ docs/The SANROC story.pdf (Accessed 13 December 2106).

Dunn, J., "Reconciliation and Rugby in Post-Apartheid South Africa", Seminar Paper, Levitt Summer Research Fellowship, Hamilton College, New York, 2009.

Dyreson, M., "Globalizing the Nation-Making Process: Modern Sport in World History", International Journal of the History of Sport, 20, 1 (2003).

Gutsche, T., Old Gold: The History of the Wanderers Club (Howard Timmins, Cape Town, 1966).

Haasbroek, J., "Rolskaatsbane in Bloemfontein, 1909-1910: Rolskaatsbane in Bloemfontein Gedurende die Republikeinse Tydperk", Navorsinge van die Nasionale Museum / Researches of the National Museum, 14, 2 (1998).

Hedley, C. "The Myth of Hockey and Identity in Paul Quarrington's King Leary", available at https://read.aupress.ca/read/writing-the-body-inmotion/section/99d09778-ab2c-43e0-89a4-7e36a62f922d (Accessed 10 September 2020).

Huddleston, T., Naught for Your Comfort (Collins, Glasgow, 1956).

Jakoet, Ismail, Private Collection, Cape Town. Correspondence, South African NonRacial Olympic Committee: Sam Ramsamy - HE Roger Bambuck, Secretary of State for Youth and Sport, Re. Collaboration with Apartheid South Africa, 7 August 1989. 
Johannesburg Ice Skating Company, Souvenir of the Opening of "Niagara", Johannesburg, 4 November 1911.

Leeworthy, D., "The Skaters of Sydney and Streatham: Exporting Hockey to the British Empire between the Wars", Paper presented at the "Putting it on Ice" Hockey Conference, Saint Mary's University, Halifax, Nova Scotia, 12-14 July 2012. Available from URL http://ftp.stmarys.ca/webfiles/21Leeworthy (Accessed 20 June 2018).

Leeworthy, D., "Skating on the Border: Hockey, Class, and Commerce in Interwar Britain", Histoire Sociale / Social History, 48, 96 (2015).

Le Grange, L., "Decolonising Sport: Some Thoughts", in Cleophas, F.J. (ed.), Exploring Decolonising Themes in SA Sport History: Issues and Challenges (Sun Press, Stellenbosch, 2018).

Lorenz, S.L., "Manhood, Rivalry, and the Creation of a Canadian 'Hockey World': Media Coverage of Early Stanley Cup Hockey Challenges, 1894-1907", PhD thesis, University of Alberta, Edmonton, Canada, 2012.

Mason, D.S., "The International Hockey League and the Professionalization of Ice Hockey, 1904-1907", Journal of Sport History, 25, 1 (Spring 1998).

MacDonald, C.A., "Masculinity and Sport Revisited: A Review of Literature on Hegemonic Masculinity and Men's Ice Hockey in Canada", Canadian Graduate Journal of Sociology and Criminology, 3, 1 (Spring 2014).

McKegney, S. and Trevor, J.P., "Decolonizing the Hockey Novel", in Abdou, A. and Dopp, J. (eds), Writing the Body in Motion: A Critical Anthology on Canadian Sport Literature (Athabasca University Press, Edmonton, 2018).

Merk, M., "Days of Safari Hockey Gone: When Maple Leafs and Swiss Bears Ruled in South Africa", International Hockey Federation, 21 June 2010. Available from http://www.iihf.com/home-of-hockey/news/news-singleview/?tx ttnews\%

$\underline{\text { 5Btt news } \% 5 \mathrm{D}=4771 \& \mathrm{cHash}=\mathrm{c} 4 \mathrm{e} 72414773 \mathrm{~b} 3 \mathrm{f} 8 \mathrm{afce} 9054277578279}$ (Accessed 18 September 2017).

Merrett, C., "In nothing else are the deprivers so deprived': South African Sport, Apartheid and Foreign Relations, 1945-1971", International Journal of the History of Sport, 13, 2 (1996).

Miller, C., "A Preliminary Analysis of the Socio-economic Composition of Canada's South African War Contingents", Histoire sociale/Social History, 8, 16 (1975).

Miller, K.E., "Sport-related Identities and the 'Toxic Jock'", Journal of Sport Behavior, 32, 1 (2009).

Moore, K., “A Divergence of Interests: Canada's Role in the Politics and Sport of the British Empire During the 1920s", Canadian Journal of Sport, 21, 1 (1990).

Nauright, J., Sport, Cultures, and Identities in South Africa (David Phillip, Claremont, 1998).

Nordmark, B., “Ice Hockey in South Africa, Part 1, 1936-1980”, Wayback Machine, 2 (October 2006).

Nygård, H.M. and Gates, S., "Soft Power at Home and Abroad: Sport Diplomacy, Politics and Peace-building" International Area Studies Review, 16, 3 (2013). 
Odendaal. A., "South Africa's Black Victorians: Sport and Society in South Africa in the Nineteenth Century", in Mangan, J.A. (ed.), Pleasure, Profit, Proselytism: British Culture and Sport at Home and Abroad, 1700-1914 (Frank Cass, London, 1988).

Odendaal, A., "'The thing that is not round': The Untold Story of Black Rugby in South Africa", in Grundlingh, A.M., Odendaal A. and Spies S.B. (eds), Beyond the Tryline (Ravan Press, Johannesburg, and Ohio University Press, Athens, 1995).

Panunto, G.S., "For Club or Country? Hockey in Wartime Canada, 1939-1945", MA thesis, Carleton University, Ottawa, Canada, July 2000.

Reddy, E.S., "Cultural Boycott: Statement by Director of the U.N. Centre Against Apartheid (1984)", Palestinian Campaign for the Academic and Cultural Boycott of Israel (Pacbi) Press Briefing, BDS Movement.net, 24 November 2010. Available from https://bdsmovement.net/news/cultural-boycott-statementenuga-s-reddy-director-un-centre-against-apartheid-press-briefing (Accessed 1 March 2019).

Sauer, W., "Austria and South Africa during Apartheid", in South African Democracy Education Trust, The Road to Democracy in South Africa, Volume 3: International Solidarity, Part I (Unisa Press, Pretoria, 2008), pp 630-640.

Soares, J., "Cold War, Hot Ice: International Ice Hockey, 1947-1980", Journal of Sport History, 34, 2 (Summer 2007).

Stevens, J. and Holman, A.C., "Rinkside: New Scholarly Studies on Ice Hockey and Society", Sport in Society, 16, 3 (2013).

Stoklund, B., "The Role of the International Exhibitions in the Construction of National Cultures in the 19th Century", Ethnologia Europaea, 24, 1 (1994).

Suttner, R., "Talking to the Ancestors: National Heritage, the Freedom Charter and Nation-building in South Africa in 2005", Development Southern Africa, 23, 1 (March 2006).

Tchechankov, I., "First Triumph for South African Women”, International Ice Hockey Federation, 11 December 2019. Available from https://www.iihf.com/en/events/ 2020/wwiii/news/16572/first-triumph-forsouth-african-women (Accessed 14 September 2020).

Tennyson, B.D., “Canadian Policy towards South Africa”, Africa Today, 29, 1 (1982).

Valentine, J., "New Racism and Old Stereotypes in the National Hockey League: The 'Stacking' of Aboriginal Players into the Role of Enforcer", in Darnell, J., Joseph., S. and Nakamura, Y. (eds), Race and Sport in Canada: Intersecting Inequalities (Canadian Scholars' Press, Toronto, Canada, 2012).

Van der Merwe, F.J.G. and Cleophas, F.J., "Mapping out an Obscured South African Sport History Landscape through Edward Henderson", African Journal for Physical Health Education, Recreation and Dance, 17, 2 (2011).

Van Doesburgh, D.C., "An Injury Profile of Ice Hockey Players in South Africa”, MTech dissertation, Durban University of Technology, 2017.

Vivier, T.L., “South African Women's Ice Hockey go for Gold and Score!!!”, 11 December 2019. Available from https://www.goodthingsguy.com/sport/sahockey-world-champs/ (Accessed 14 September 2020). 
Volschenk, J. (ed.), Struggle-rugby: ' $n$ Sport in Krisis / Struggle-rugby: A Sport in Crisis (Solidariteit Navorsingsinstituut, Pretoria, 2002).

Wilson, J.J., "Skating to Armageddon: Canada, Hockey and the First World War", International Journal of the History of Sport, 22, 3 (2005). 